\title{
Behavioral Interference Between Sympatric Reindeer and Domesticated Sheep in Norway
}

\author{
Jonathan E. Colman, ${ }^{1,5}$ Diress Tsegaye, ${ }^{2,6}$ Christian Pedersen, ${ }^{8}$ Ruben Eidesen, ${ }^{3,9}$ Herbjørg Arntsen, ${ }^{6}$ \\ Øystein Holand, ${ }^{10}$ Alex Mann, ${ }^{2}$ Eigil Reimers, ${ }^{4}$ and Stein R. Moe
}

Authors are ${ }^{1}$ Associate Professor, ${ }^{2}$ Researcher, ${ }^{3}$ Research Associate, and ${ }^{8}$ Professor, Department of Biology, University of Oslo, N-0316 Oslo, Norway; ${ }^{5}$ Associate Professor, ${ }^{6}$ Researcher, and ${ }^{7}$ Professor, Department of Ecology and Natural Resource Management, Norwegian University of Life Sciences, N-1432 Ås, Norway; ${ }^{8}$ Researcher Scientist, Norwegian Forest and Landscape Institute, N-1431 Ås, Norway; ${ }^{9}$ Research Associate, University Centre in Svalbard (UNIS), 9170 Longyearbyen, Norway; and ${ }^{10}$ Professor, Department of Animal and Aquaculture Sciences, Norwegian University of Life Sciences, N-1432 Ass, Norway.

\begin{abstract}
Interspecific interaction among sympatric ungulates is important in management and conservation. We investigated behavioral interference between sympatric wild or semidomestic reindeer (Rangifer tarandus tarandus) and sheep (Ovis aries) in two field studies and one enclosure experiment. For free-ranging wild and semidomestic reindeer, interference between the two species increased with decreasing distances, occurring only at less than $200 \mathrm{~m}$ and $30 \mathrm{~m}$, for wild and semidomestic reindeer, respectively, and neither species consistently dominated the other. In a controlled, duplicated experiment we tested interference and confrontations at the feeding patch level among semidomestic reindeer and sheep within $40 \times 50 \mathrm{~m}$ enclosures. When new reindeer or sheep were introduced into enclosures already occupied by reindeer, new reindeer resulted in significantly more interference and confrontations among individuals compared to new sheep; i.e., intraspecific interference was more prevalent than interspecific interference at equal densities. For all study areas, confrontations decreased with time after "first encounter," indicating cohabituation. A sympatric use of pastures was not visually disruptive for recorded grazing behavior for either species.
\end{abstract}

\section{Resumen}

La interacción inter-específica entre ungulados que ocupan el mismo habitat es importante para el manejo y la observación. Investigamos la interferencia en el comportamiento entre el reno silvestre o semi-doméstico (Rangifer tarandus tarandus) y la oveja (Ovis aries) en dos campos de estudio y un exclusión experimental. Para renos silvestres o semi-domésticos que pastorean libremente la interferencia entre las dos especies aumenta conforme se reduce la distancia ocurriendo, solo a menos de 200 y 30 metros para los renos silvestres y renos semi-domésticos respectivamente y ninguna de las especies domino a la otra. En un experimento controlado y duplicado probamos la interferencia y confrontación a nivel de parche de alimentación entre renos semi-domésticos y ovejas dentro de una exclusión de $40 \times 50$ metros. Cuando los renos u ovejas nuevos fueron introducidos en la exclusión donde ya estaba ocupada por otros renos, los nuevos renos resultaron en una interferencia y confrontación significativa mayor entre individuos comparada con ovejas nuevas; ejm. Interferencia intraespecífica fue más acentuada que interferencia interespecífica en densidades iguales. Para todas las áreas de estudio las confrontaciones disminuyeron con el tiempo después del primer encuentro indicando cohabitación. Un uso simpátrico del pastizal no fue visualmente disruptivo para el comportamiento de pastoreo registrado en ambas especies.

Key Words: Enclosure, free-ranging, habituation, interspecific interactions, summer pastures, sympatric ungulates

\section{INTRODUCTION}

Interspecific interactions such as confrontations and displacement (i.e., interference) are a major concern of wildlife management and conservation of sympatric ungulates (Putman 1996; Arsenault and Owen-Smith 2002). Such interactions may derive from competition because livestock often aggregate at high densities and could have niches similar to those of the wild herbivores (Colman et al. 2009). However, whether or not competition occurs between livestock and wild ungulates, and

Research was funded in part by the Norwegian Science Council, Reindeer Herding Development Fund, Norway Sheep and Goat Association, Trygve Gotaas Fond, Statskog i Sør, and E. Reimers Reindeer Research Fund.

Correspondence: Diress Tsegaye, Dept of Biology, University of Oslo, Pb. 1066 Blindern, N-0316 Oslo, Norway. Email: d.t.alemu@bio.uio.no or diress62@yahoo.com

Manuscript received 2 June 2011; manuscript accepted 19 December 2011. its degree, is often disputed (Madhusudan 2004; Mishra et al. 2004). Generally competition between species can be indirect through reduction in available resources (exploitation competition) or direct through behavioral interactions (interference competition and displacement). There can also be indirect interference in the form of, for example, aversion toward excrement (Schoener 1983; Putman 1996; Moe et al. 1999). Interspecific competition may be especially prevalent when new species or additional animals are introduced (Voeten and Prins 1999; Forsyth 2000) and/or reintroduced (Reed 2001; Fischer and Gates 2005) into an already established guild of herbivores. If interference and/or displacement between the two species occurs, one or both of the species might lose access to important food resources and/or reduce vital foraging time due to the other's presence. Consequently body condition, and ultimately reproduction and survival, may be reduced for both species if pasture or foraging time is limited (Colman et al. 
2003). The importance of animal density in grazing dynamics is well established (Hutchings and Gordon 2001; Person et al. 2003). However, potential differences in inter- versus intraspecific interactions on common pastures are presently unknown.

The last remnants of wild reindeer populations in Europe are found in Norway, and much of the country's land area is used by semidomestic reindeer herded by Sámi reindeer pastoralists (Colman et al. 2009). In Norway domestic sheep, almost exclusively ewes with lambs, are the most common sympatric ungulates sharing alpine ranges with wild and semidomestic reindeer (Skogland 1984; Colman et al. 2009). Approximately 2.5 million sheep are released onto outlying pastures every summer (Kausrud et al. 2006), greatly increasing the herbivore density on the shared range. There has been an ongoing debate in the last few decades concerning the issue of interactions between reindeer and sheep (Colman et al. 2009). Some claim that sheep show aggressive behavior toward reindeer and displace them in areas with poor forage (Colman 2000). However, there are divergent opinions among the stakeholders (mainly land owners, reindeer herdsmen, and sheep farmers) regarding the interaction and how the two species are affected by one another.

Studies show a considerable overlap in diet between reindeer and sheep on common summer pastures in Norway (Skogland 1984; Mysterud 2000). Reindeer and sheep utilize similar habitats, yet with little temporal overlap (Colman et al. 2009). The present study, like those above, focused predominately on interactions between ewes with lambs and female reindeer with calves. Although the relationship between resource overlap and interspecific competition is not clear (Abrams 1980; Lawlor 1980), the high similarity in diet and habitat use between the species suggests that competitive interaction is likely to occur when shared food resources are limited (de Boer and Prins 1990; Putman 1996). Segregation of the species despite similar resource use may, among other explanations, be the result of interference with behavioral dominance or displacement by one species toward the other (Ferretti et al. 2011). Research on interference between free-ranging wildlife and domestic stock are rare (but see Colman 2000). Further research on delineating the types of interaction may improve the management of the species and the ecological systems they share and assist communication between the different stakeholders.

Our study focused on behavioural interference between sheep and reindeer. Interference was observed in enclosures or on open rangeland in southern Norway (sympatric wild reindeer) and northern Norway (semidomesticated reindeer). We analyzed behavioral reactions of the two species toward each other through direct observations, focusing mostly on the scale of feeding patches. We tested the hypothesis that reindeer and sheep exhibit interference with each other, specifically forcing one species to avoid areas used by the other in both the wild and semidomestic reindeer summer grazing areas. We use the term interference to mean that at least one of the species interrupts the other. An interruption was defined as a change in behavior to an alert or stressed state (as defined in Thomson 1977) for at least $2 \mathrm{~min}$. Neutral interaction is when interference occurs with no confrontation. A confrontation means that during the course of interference one species exhibits aggressive behavior toward the other. Displacement means that one species moves away from the other as a result of interference that is usually, but not necessarily, confrontational. Based on unpublished studies, personal observations, and claims from user groups, we predicted that as the distance between the species decreases (1) the likelihood of interference that leads to displacement increases and (2) one species will always displace the other once the distance falls below $200 \mathrm{~m}$, meaning there is no neutral behavior/tolerance at this patch scale. The wild reindeer and sheep study and information from user groups provided the basis for the enclosure experiment, in which reindeer or sheep were added to an existing (resident) group of reindeer inside $2000 \mathrm{~m}^{2}$ enclosures. Here we additionally predicted that the average distance among the individual resident reindeer would decrease following the introduction of new reindeer or sheep, and increase again as the animals became more tolerant toward each other. We further predicted that the distance between the two species would be greater at the start of the experiment than at its end, and decrease to the extent that the species cohabituated.

\section{MATERIALS AND METHODS}

\section{Study Sites}

The study draws on data collected in different periods at three sites: (1) a field study of wild reindeer in Setesdal-Ryfylke $\left(59^{\circ} 5^{\prime} \mathrm{N} ; 7^{\circ} 12^{\prime} \mathrm{E}\right)$, southern Norway, during July and August 1997 and 1998 (Setesdal study); (2) a field study of semidomestic reindeer in Øksfjord in the summer grazing area of the Joahkonjárga Sami reindeer herding district $\left(70^{\circ} 10^{\prime} \mathrm{N}\right.$, $22^{\circ} 30^{\prime} \mathrm{E}$ ) in West Finnmark, northern Norway, in early June to mid-August 2006 (Øksfjord study); and (3) an enclosure experiment in Bognelvdalen $\left(69^{\circ} 59^{\prime} \mathrm{N}, 22^{\circ} 19^{\prime} \mathrm{E}\right)$ in Finnmark, northern Norway, in June 1999 (Fig. 1).

\section{Field Studies}

The Setesdal study was conducted in an alpine area that ranges in altitude from 800 to 1200 m.a.s.l. and is mostly covered by bare bedrock, with productive areas limited to the valley bottoms. Setesdal supports the second largest wild reindeer area in Norway $\left(6000 \mathrm{~km}^{2}\right)$. The winter population during the study period was approximately 3000 reindeer $(0.5$ reindeer $\cdot \mathrm{km}^{-2}$ ), with an annual recruitment of 800 calves (Colman 2000). During summer (June-August/September) 180000 sheep (30.0 sheep $\cdot \mathrm{km}^{-2}$ including ewes and lambs) were released and ranged freely in the mountain range (Colman 2000).

In the Øksfjord study, data collection was restricted to the mid-western half of the $272 \mathrm{~km}^{2}$ peninsula and a core area of the Indre Lokkarfjorden (the inner Lokkar fjord valley) with elevations ranging from sea level to 830 m.a.s.l. The core area, encompassing approximately $35 \mathrm{~km}^{2}$, belongs to the slightly oceanic vegetation section dominated by high mountains, where valley bottoms rich in vegetation are enclosed by steep mountainsides. Approximately 6000 semidomestic reindeer (22.1 reindeer $\cdot \mathrm{km}^{-2}$ for the entire summer range), comprising mostly (93\% of adults) females and calves, arrived sporadically over the month of June. Approximately 650 sheep, comprising ewes and lambs, arrived during the second and third weeks of June (Arntsen 2007). When the two species were present in the 


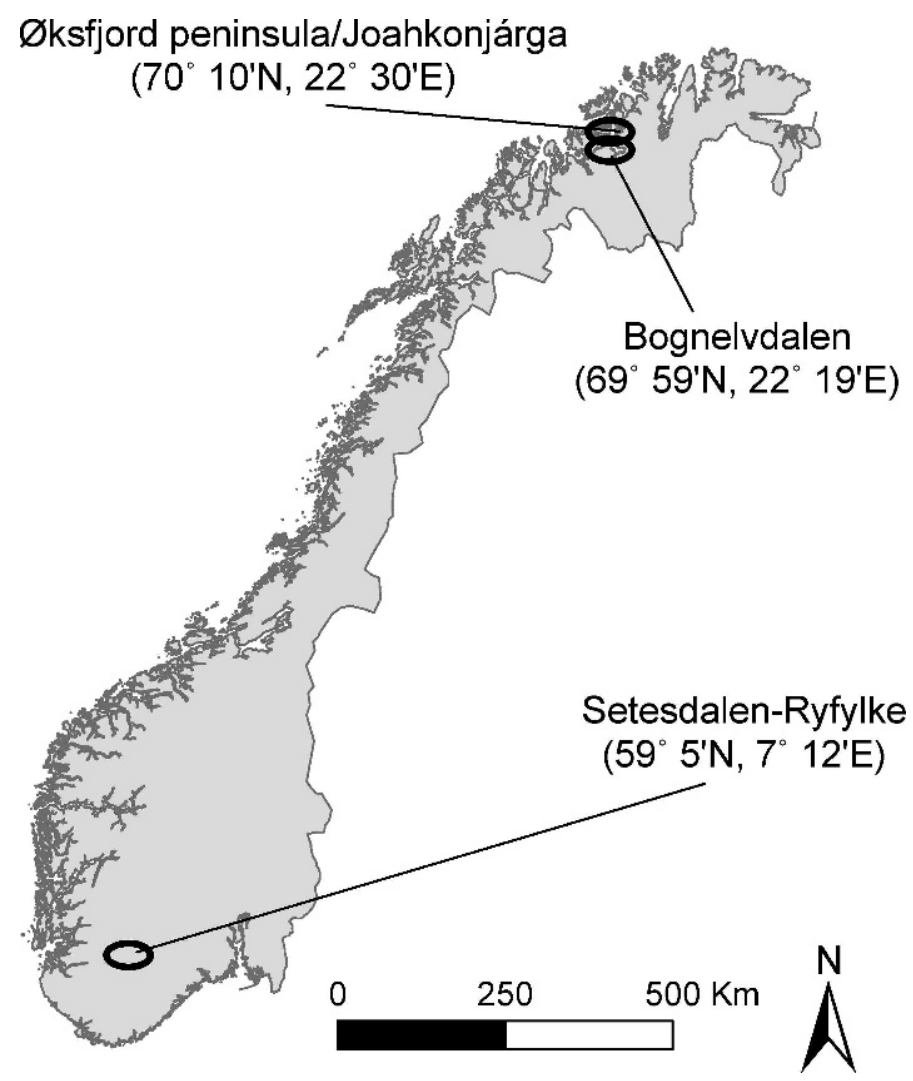

Figure 1. Location of the study areas: Experimental enclosure site (Bognelvdalen), free-ranging semidomesticated reindeer area in Øksfjord (Joahkonjarga), and wild reindeer area (Setesdal), Norway.

core area at the same time, the densities and group sizes were almost equal (Arntsen 2007).

In both the Setesdal and Øksfjord studies, reindeer were scattered over the entire study area, while sheep were mostly resident in core areas where spatial and temporal niche overlap occurs between the two species (Colman 2000). We observed female reindeer with calves and ewes with lambs with the help of binoculars $(12-42 \times)$ and spotting scopes (15-60× zoom). When the species were within $1000 \mathrm{~m}$ of each other the distance between them was determined using binoculars with built-in laser rangefinders able to measure distances of up to $1.2 \mathrm{~km}$ and/or estimated from animal positions drawn on maps (1:50 000).

Distances between reindeer and sheep and the dominant behavior of respective groups under observation, along with date and time of day, were recorded using the method of instantaneous scan sampling (Altmann 1974) at 15 -min intervals $24 \mathrm{~h}$ a day (Colman et al. 2003), in order to provide a systematic recording of distances between groups of the two species. The numbers of observation days were 30 and 31 for Oksfjørd and Setsdal, respectively. To record interference and the respective groups' behavioral reactions toward each other, ad libitum registrations on a continuous basis were begun when groups of two species were within $1 \mathrm{~km}$ of each other in Øksfjord and $200 \mathrm{~m}$ in Setesdal (Colman 2000; Côté 2000). Groups of animals of the same species were considered as single observation units.

A "meeting" occurred when one species became alert to the presence of another and could potentially interfere with each other, but had yet to exhibit any further behavioral reactions. Behavioral reactions (alertness, standing, walking away, grouping together, running away, and ignoring) were recorded from the instant interference was observed between two groups (Colman et al. 2009). The closest distance between the groups was registered. The reaction of each species toward the presence of the other was deemed neutral if no confrontation occurred during a meeting. If a confrontation occurred, a winner and loser species was assigned. The loser was defined as the species that was displaced, while the winner was the group that displaced the losing group. If both species were displaced, we assigned both as losers.

\section{Enclosure Experiment}

The enclosure experiment was conducted in an open farm landscape (Fig. 1). Based on recommendations from reindeer herdsmen (Mathis A. Gaup, personal communication, May 1999) and sheep farmers (Ingebjørg and Asbjørn Jensen, personal communication, May 1999) and sizes of feeding patches for free-ranging animals for both species (Colman et al. 2009), six $40 \times 50 \mathrm{~m}$ enclosures were used. The fences between the enclosures were cased with fabric to prevent visible contact between the animals in different enclosures. All corners out to $3 \mathrm{~m}$ along the fence were covered with the same fabric to provide animals with shelter and shade. To provide the animals with drinking water, two buckets with running water were placed opposite each other in the middle of the $50-\mathrm{m}$ sides in each enclosure. The animals foraged on natural vegetation.

The enclosures were allocated to three treatments: (1) reindeer treatment group (RTG; enclosures 1 and 4); (2) sheep treatment group (STG; enclosures 2 and 5); and (3) control group (CG; enclosures 3 and 6). The experiment was divided into three consecutive periods of 6 to $8 \mathrm{~d}$ each. At the beginning of the first period (9-16 June 1999), three female reindeer yearlings were released into each of the six enclosures. Reindeer were chosen as the "resident" species because they are present in the area before sheep are released in early summer. Females were chosen because they make up over $90 \%$ of the adult portion of semidomestic reindeer herds and are considered to be more sensitive to disturbances than males. Females are also smaller than males and thus rather similar in size to ewes (Mysterud 2000). These 18 female reindeer were referred to as the resident reindeer, i.e., the test animals that remained in the enclosures throughout all periods. At the beginning of the second period (17-22 June), three ewes were released into the STG enclosures (2 and 5), and three new yearling female reindeer were released into the RTG enclosures (1 and 4). These six sheep and six new reindeer will be referred to as the visiting animals. At the end of period 2, the visiting animals were removed from the enclosures, and the resident reindeer remained for period 3 (23-29 June). The resident reindeer in the CG enclosures (3 and 6) served as controls throughout the experiment; they were not visited by new animals.

Reindeer and sheep are both social, gregarious animals that respond toward danger by uniting into a tight group with individuals standing close $(\leq 1 \mathrm{~m})$ to each other until the stimulus is no longer perceived as an immediate danger. They resume undisturbed behavior and move and graze farther away from each other when not disturbed (Skogland 1989). To test 
the behavioral reaction of the resident reindeer to the introduction of the visiting animals, we measured the distances between individuals within and between the resident and visiting groups. Similar to the free-ranging studies, we used Altmann's (1974) instantaneous scan sampling, but at 10-min intervals, and ad libitum sampling of rare events on a continuous basis for interferences. Scan observations $24 \mathrm{~h}$ a day provided systematic registrations, and distances were measured by using the length of the animals (approximately $1.5 \mathrm{~m}$ ) and the fence poles surrounding each enclosure (poles were placed at exactly $1-\mathrm{m}$ intervals). Distances were first estimated between individuals within the resident animals, as well as between individuals within the visiting animals, and then also between the closest resident reindeer to the closest visiting animal. The ad libitum sampling focused on confrontations because of the forced proximity and recorded every visible confrontation between individuals in each of the enclosures. The individual that terminated the confrontation by moving away from the other individual was deemed the "loser," and the animal remaining after the confrontation, the "winner" (Fairbanks 1994). The animals wore collars marked with large numbers. The collar number of the winner and loser and type of behavior (i.e., displace, head threat, chase, kick or push, and combinations thereof) were recorded (Thompson 1993). Additional details about the study area, experimental setup, animal activity data recorded, and other general methods are given in Colman et al. (2004).

\section{Statistical Analyses}

To analyze data from the summer field studies, we used a generalized linear model (GLM) that tested the behavioral interference of species when reindeer and sheep were within $1000 \mathrm{~m}$ of each other in Øksfjord and Setesdal. Interferences (confrontation vs. neutral) were analyzed using a generalized linear model with binomial error (link=logit), whereas the outcome of confrontation were analyzed using GLM with Poisson error $(\operatorname{link}=\log )$. As confrontation only occurred at distances less than $30 \mathrm{~m}$ and $200 \mathrm{~m}$ in Øksfjord and Setesdal, respectively, the remaining distances were excluded from the analysis to strengthen statistical independence. For Setesdal, data for two summers (1997 and 1998) were analyzed together. We also compared the Øksfjord and Setesdal sites to test whether free-ranging wild and semidomesticated reindeer differed in their behavioral reaction when interacting with sheep. The response variables were interferences (confrontation vs. neutral) and who won the confrontation, with distance and species as explanatory variables. Site was used as explanatory variable when confrontation was compared between the two study areas.

For the enclosure experiment, we used a generalized linear mixed effect model (GLMM) to analyze interference between the resident reindeer and visiting animals with reactions as (1) confrontation or no confrontation and (2) winning or losing a confrontation using binomial errors (Crawley 2007). Treatment groups (CG, RTG, and STG) and periods (9-16 June: pretreatment; 17-22 June as a continuous variable: treatment; and 23-29 June: post-treatment) were explanatory variables. We did separate analyses for interference in period 2 and tested for time while together from 17 to 22 June to investigate possible cohabituation from "first encounter" and until the last day in period 2. To avoid pseudo-replication, "enclosure" (i.e., group) was included as a random factor (Pinheiro and Bates 2000) in the analysis using the "nlme" package in R. We also compared distances (response variable) among individuals of the same species for RTG and STG treatments, and between the two species in STG treatment in relation to time (days: explanatory variable) in period 2 to further investigate cohabituation using the GLMM. Enclosure was used as a random factor to avoid pseudo-replication. All analyses were performed in $\mathrm{R}$ version 2.12.0 (R Development Core Team 2010).

\section{RESULTS}

\section{Interference Between Free-Ranging Reindeer and Sheep on Summer Ranges}

When sheep were released into outlying pasture during summer in both free-ranging study areas, confrontations between the two species increased as distance decreased within $1000 \mathrm{~m}$ of each other (Table 1). The percent meetings out of the total recorded scans first increased until $200 \mathrm{~m}$ and then decreased with increasing distance in Setesdal, and varied among distance intervals in Øksfjord (Table 1). Meetings between the two species within $30 \mathrm{~m}$ were higher $(16 \%)$ in Øksfjord compared to $3 \%$ in Setesdal (Table 1). The average distance between reindeer and sheep groups for the entire period was $94.3 \pm 5.7 \mathrm{~m}$ (mean $\pm \mathrm{SD}$ ) and $281.3 \pm 12.8 \mathrm{~m}$ in Øksfjord and Setesdal, respectively. The minimum recorded distance between the reindeer and sheep groups was $0.5 \mathrm{~m}$ and $5 \mathrm{~m}$ in Øksfjord and Setesdal, respectively.

The percent confrontations out of the total amount of meetings within $1000 \mathrm{~m}$ for both study areas, increased as the two species came closer (Table 1). However, confrontations between reindeer and sheep were observed only when the species were within $30 \mathrm{~m}$ and $200 \mathrm{~m}$ of each other in Øksfjord and Setesdal, respectively. Confrontations decrease with increasing distance between groups, and most meetings in both the study areas resulted in neutral behavioral reactions (Table 1). In Øksfjord, 81\% (54 out of 67) of meetings within $30 \mathrm{~m}$ resulted in neutral behavior reactions. Similarly in Setesdal, 87\% (201 out of 231) meetings within $200 \mathrm{~m}$ resulted in neutral behavioral interactions (Table 1). There was no significant difference between which species won or lost a confrontation, although reindeer won slightly more confrontations compared to sheep when confrontation occurred within 0-30 $\mathrm{m}$ in Øksfjord and 0-200 $\mathrm{m}$ in Setesdal (Table 2). Overall, a significantly higher level of confrontations was recorded in Setesdal compared to Øksfjord (Table 2; $P=0.002)$.

\section{Confrontations Between Reindeer and Sheep in Enclosure}

Total number of confrontations were higher for RTG $(n=187$, resident vs. visiting reindeer) than STG $(n=144$, resident reindeer vs. visiting sheep) in period 2 (Table 3). There were no significant differences in amount of confrontations for the CG (resident vs. resident reindeer) between the pre-treatment $(5.83 \pm 5.06$, Mean \pm SD) and treatment $(5.00 \pm 4.00)$ periods (Fig. 2; Table 4). However, the post-treatment period had significantly lower confrontation $(2.41 \pm 2.43)$ compared to 
Table 1. Number and percent of meetings leading to interference and/or confrontation at distance intervals within $1000 \mathrm{~m}$ between free-ranging sheep and semidomestic reindeer during summer 2006 in Øksfjord and wild reindeer during the summers of 1997 and 1998 in Setesdal, Norway.

\begin{tabular}{|c|c|c|c|c|c|c|c|c|}
\hline \multirow[b]{2}{*}{$\begin{array}{l}\text { Distance } \\
\text { interval (m) }\end{array}$} & \multicolumn{4}{|c|}{$\emptyset$ ksfjord } & \multicolumn{4}{|c|}{ Setesdal } \\
\hline & No. of meetings & $\%$ Meetings $^{1}$ & $\%$ Neutral $^{2}$ & $\%$ Confrontation $^{3}$ & $\begin{array}{c}\text { No. of } \\
\text { meetings }\end{array}$ & $\%$ Meetings $^{1}$ & $\%$ Neutral $^{2}$ & $\%$ Confrontation ${ }^{3}$ \\
\hline $0-30$ & 67 & 16.22 & 80.60 & 19.40 & 13 & 3.20 & 23.08 & 76.92 \\
\hline $30-50$ & 52 & 12.59 & 100 & 0 & 27 & 6.65 & 70.37 & 29.63 \\
\hline 50-100 & 49 & 11.86 & 100 & 0 & 95 & 23.40 & 90.53 & 9.47 \\
\hline $100-200$ & 25 & 6.05 & 100 & 0 & 96 & 23.65 & 96.88 & 3.12 \\
\hline $200-500$ & 64 & 15.50 & 100 & 0 & 78 & 19.21 & 100 & 0 \\
\hline $500-1000$ & 26 & 6.30 & 100 & 0 & 32 & 7.88 & 100 & 0 \\
\hline Total scans & 413 & & & & 406 & & & \\
\hline
\end{tabular}

$1 \%$ Meetings $=$ (number meetings/total scans $) \times 100$.

$2 \%$ Neutral $=$ (number of neutral interferences/number of meetings $) \times 100$ for each distance category.

$3 \%$ Confrontation $=$ (number of confrontations/number of meetings) $\times 100$ for each distance category.

pre- and treatment periods for the CG (Fig. 2; Table 4). A significantly higher number of confrontations were recorded in the RTG $(25.17 \pm 9.94)$ and STG $(16.75 \pm 9.26)$ for period 2 (i.e., when visiting sheep and reindeer were introduced in the treatment enclosures) compared to period 1 (RTG: $6.91 \pm 6.64$; STG: $2.75 \pm 3.08$ ) and period 3 (RTG: $1.91 \pm 2.68$; STG: $0.25 \pm 0.62)$ (Fig. 2; Table 4).

Considering only period 2, number of confrontations was significantly higher in RTG $(P=0.02$; resident vs. visiting reindeer) and STG $(P=0.04$; resident reindeer vs. visiting sheep) treatments compared to the CG (among resident reindeer) (Fig. 2; Table 4). When displacement occurred, resident reindeer lost $(92 \%)$ significantly more often than sheep $(8 \%)$ in period 2 (Table $4 ; P=0.001$ ). Out of the 187 confrontations in the RTG in period 2 (Table 3), there was no significant difference in winning confrontations between resident $(48 \%)$ and visiting reindeer $(52 \%)$ (Table $4 ; P=0.15)$.

The average distance between individuals of the same species differed significantly between resident reindeer $(5.11 \pm 3.36 \mathrm{~m})$ and visiting sheep $(2.39 \pm 1.91 \mathrm{~m})$ for STG in period 2 (Fig. 3A; Table 5). However, it did not differ for resident $(3.51 \pm 2.26 \mathrm{~m})$ and visiting reindeer $(3.50 \pm 2.27 \mathrm{~m})$ in RTG in period 2 (Fig. 3B; Table 5). Average distance between individuals of the same species increased significantly (Figs. 3A and 3B; Table 5) (indicating a more relaxed behavior and less need for "security in numbers" among individuals of the same species), while distance among individuals between resident reindeer and visiting sheep decreased significantly with time

Table 2. The proportion of confrontation and number of times confrontations were won within 0-30 m and 0-200 $\mathrm{m}$ for reindeer and sheep in Øksfjord (summer 2006) and Setesdal (summer 1997-1998), Norway. Interferences (1a, 2a, and 3) were analyzed using generalized linear model with binomial error (link = logit), whereas the outcome of confrontation (1b and $2 b$ ) were analyzed using generalized linear model with Poisson error (link $=\log$ ). Separate analysis was done for each subdivided headings. Neutral behavior, reindeer, and Øksfjord were used as reference levels for interference, species, and site categorical variables, respectively.

\begin{tabular}{|c|c|c|c|c|c|}
\hline Effect & $\mathrm{df}$ & Estimate & SE & $z$ value & $P$ value \\
\hline \multicolumn{6}{|l|}{ 1. Øksfjord peninsula (0-30 m) } \\
\hline \multicolumn{6}{|l|}{ a. Confrontation } \\
\hline Intercept & & -0.25 & 0.55 & -0.44 & 0.66 \\
\hline Distance $(m)$ & 1 & -0.08 & 0.04 & -2.16 & 0.03 \\
\hline \multicolumn{6}{|c|}{ b. Outcome of confrontation between species } \\
\hline Intercept & & -0.61 & 0.41 & -1.49 & 0.14 \\
\hline Sheep & 1 & -0.09 & 0.61 & -0.14 & 0.89 \\
\hline \multicolumn{6}{|l|}{ 2. Setesdal $(0-200 \mathrm{~m})$} \\
\hline \multicolumn{6}{|l|}{ a. Confrontation } \\
\hline Intercept & & 0.20 & 0.42 & 0.49 & 0.62 \\
\hline Distance $(\mathrm{m})$ & 1 & -0.03 & 0.01 & -4.78 & $<0.0001$ \\
\hline \multicolumn{6}{|c|}{ b. Outcome of confrontation between species } \\
\hline Intercept & & 0.05 & 0.23 & 0.24 & 0.81 \\
\hline Sheep & 1 & -0.55 & 0.38 & -1.44 & 0.15 \\
\hline \multicolumn{6}{|c|}{ 3. Comparison of confrontation between Setesdal and Øksfjord } \\
\hline Intercept & & -0.18 & 0.50 & -0.36 & 0.72 \\
\hline Setsdal & 1 & 1.96 & 0.64 & 3.07 & 0.002 \\
\hline Distance (m) & 1 & -0.09 & 0.03 & -2.72 & 0.01 \\
\hline
\end{tabular}


Table 3. Sum of confrontations recorded per treatment group in the three periods, and who won a confrontation when confrontations occurred in period 2. The sums are the number of confrontations observed (1) among resident, (2) among visiting, and (3) between resident and visiting animals for all days in each period of the two replications (i.e., enclosures) for each treatment group. CG, RTG, and STG refer to control (only resident reindeer), reindeer (resident and visiting reindeer), and reindeer-sheep (resident reindeer and visiting sheep) treatment groups, respectively.

\begin{tabular}{|c|c|c|c|c|c|c|c|}
\hline \multirow[b]{2}{*}{ Period } & \multirow[b]{2}{*}{ Treatment } & \multicolumn{4}{|c|}{ Confrontation (sum) } & \multicolumn{2}{|c|}{ Won (sum) } \\
\hline & & Total & $\begin{array}{l}\text { Resident reindeer vs. } \\
\text { resident reindeer }\end{array}$ & $\begin{array}{c}\text { Visiting animals } \\
\text { vs. visiting animals }\end{array}$ & $\begin{array}{l}\text { Resident reindeer } \\
\text { vs. visiting animals }\end{array}$ & $\begin{array}{l}\text { Resident } \\
\text { reindeer }\end{array}$ & $\begin{array}{l}\text { Visiting } \\
\text { animals }\end{array}$ \\
\hline \multirow[t]{3}{*}{1 (9-16 June 1999) } & CG & 70 & 70 & & & & \\
\hline & RTG & 83 & 83 & & & & \\
\hline & STG & 33 & 33 & & & & \\
\hline \multirow[t]{3}{*}{2 (17-22 June 1999) } & $C G$ & 60 & 60 & & & & \\
\hline & RTG & 302 & 78 & 37 & 187 & 89 & 98 \\
\hline & STG & 201 & 18 & 39 & 144 & 11 & 133 \\
\hline \multirow[t]{3}{*}{3 (23-29 June 1999) } & CG & 29 & 29 & & & & \\
\hline & RTG & 23 & 23 & & & & \\
\hline & STG & 3 & 3 & & & & \\
\hline
\end{tabular}

after "first encounter" (Fig. 3C; Table 5); i.e., the resident reindeer and visiting sheep cohabituated and became one integrated group dispersed evenly within the enclosure. However, the average distance was shorter between individuals of the same species/group (Figs. 3A and 3B) and longer between confronting species (Fig. 3C) during the first $2 \mathrm{~d}$ in period 2 (i.e., during higher number of confrontations upon "first encounter"). We observed that individuals of both resident and visiting animals huddled together separately into two separate groups on separate sides of the enclosures during "first encounter" in period 2.

Over the course of period 2, the individuals of the same group/species spread out again, indicating a return to relaxed behavior and cohabituation toward each other. For the STG treatment (Figs. 3A and 3C), the two species began period 2

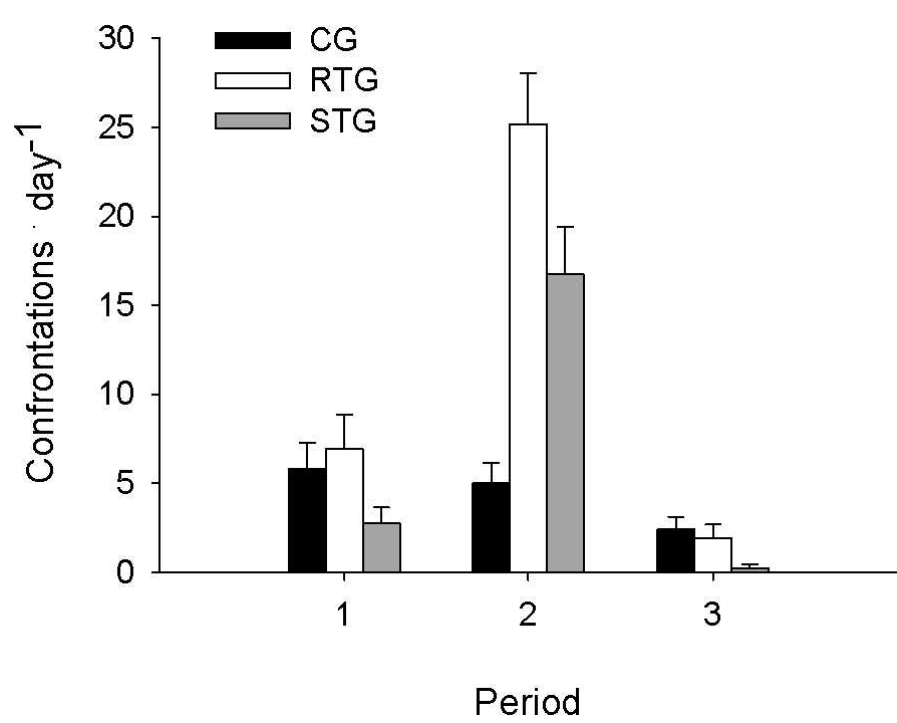

Figure 2. Number of confrontations (mean $\pm \mathrm{SE}$ ) between resident reindeer in period 1 (9-16 June 1999) and 3 (22-29 June 1999), and resident reindeer vs. visiting animals in period 2 (17-22 June 1999). CG, RTG, and STG refer to control (only resident reindeer), reindeer (resident and visiting reindeer), and sheep-reindeer (resident reindeer and visiting sheep) treatment groups, respectively. relatively far apart from each other and in two separate groups (Fig. 3C), but then increased their distance between individuals of the same species (Fig. 3A) and decreased their distance amongst each other significantly (Fig. 3C). However, a slight increase in distance between resident reindeer and visiting sheep at the last day of period 2 was likely due to disturbances by human activities (farming) near the enclosures. Period 3 (days 23-29) showed all individuals resuming relaxed behavior in both treatment groups.

\section{DISCUSSION}

Reindeer and sheep are both ruminants and show an overlap in resource use (Colman 2000; Mysterud 2000) that may result in the displacement of one species by the other. Our findings from both the experimental and field studies, however, show that confrontations and displacement between the two species are rare. The two species shared the available resources with little or no aggression, both in the enclosures and for most of the grazing season on open ranges. This implies limited interference between the two species while sharing summer pastures in Norway. Our results from the field studies support previous observations of no interspecific exclusion in ruminants through aggressive behavior (Bartos et al. 2002; Prins et al. 2006).

The proportion of winning a confrontation was similar for reindeer and sheep in the field study, indicating that neither was consistently dominant over the other. This could be expected, because intraspecific aggressiveness in ewes (Lynch et al. 1992) and in reindeer females in fostering herds (Skogland 1984) is relatively rare. This may also be due to the fact that aggression is often linked to the availability of essential but scarce resources (Eckardt and Zuberbuhler 2004; Sushma and Singh 2006). The probability of displacement events between freeranging reindeer and sheep did not vary between wild and semidomesticated reindeer areas, as the majority of meetings between the two species result in neutral interactions.

The results of the current study revealed that reindeer and sheep should be within relatively proximity of one another before confrontations occurred $(30 \mathrm{~m}$ for semidomestic and $200 \mathrm{~m}$ for wild reindeer). These distances may be established as 
Table 4. Behavioral reactions during confrontations between resident reindeer and visiting animals (new reindeer and sheep) under enclosure experiment in Bognelvdalen, northern Norway, analyzed using generalized linear mixed effect model. Enclosure was used as a random factor. Separate analysis was done for each numbered headings. Period 1, CG, and resident reindeer were used as reference levels for period, treatment, and species categorical variables, respectively. CG, RTG, and STG refer to control (only resident reindeer), reindeer (resident and visiting reindeer), and reindeer-sheep (resident reindeer and visiting sheep) treatment groups, respectively.

\begin{tabular}{|c|c|c|c|c|c|}
\hline Effect & df & Estimate & SE & $t$ value & $P$ value \\
\hline \multicolumn{6}{|c|}{ 1. Confrontations in different periods } \\
\hline Intercept & & 1.59 & 0.33 & 4.80 & $<0.0001$ \\
\hline RTG & 1 & 0.05 & 0.47 & 0.10 & 0.93 \\
\hline STG & 1 & -0.54 & 0.47 & -1.16 & 0.33 \\
\hline Period 2 & 1 & -0.02 & 0.30 & -0.06 & 0.95 \\
\hline Period 3 & 1 & -0.66 & 0.29 & -2.22 & 0.03 \\
\hline $\mathrm{RTG} \times$ period 2 & 1 & 1.58 & 0.42 & 3.78 & 0.0003 \\
\hline $\mathrm{RTG} \times$ period 3 & 1 & 1.67 & 0.42 & 4.00 & 0.0001 \\
\hline STG $\times$ period 2 & 1 & -0.23 & 0.42 & -0.55 & 0.58 \\
\hline STG $\times$ period 3 & 1 & -0.24 & 0.42 & -0.57 & 0.57 \\
\hline \multicolumn{6}{|c|}{ 2. Confrontations in period 2} \\
\hline Intercept & & 3.97 & 1.07 & 3.70 & 0.001 \\
\hline RTG & 1 & 1.63 & 0.32 & 5.04 & 0.02 \\
\hline STG & 1 & 1.13 & 0.32 & 3.51 & 0.04 \\
\hline Days & 1 & -0.12 & 0.05 & -2.29 & 0.03 \\
\hline \multicolumn{6}{|c|}{ 3. Winning confrontations in period 2} \\
\hline Intercept & & 0.50 & 1.70 & 0.30 & 0.77 \\
\hline Visiting reindeer & 1 & 0.58 & 0.39 & 1.47 & 0.15 \\
\hline Visiting sheep & 1 & 1.37 & 0.39 & 3.51 & 0.001 \\
\hline Days & 1 & 0.03 & 0.09 & 0.30 & 0.76 \\
\hline
\end{tabular}

"minimum" distances where displacement of one by the other is an issue being considered in management of their common range. This could be important when the two species encounter each other at feeding patches. If resources are limited due to increasing densities of one or both species, or as a result of other land use changes in wild or semidomestic reindeer areas limiting patch sizes of preferred pasture (Colman et al. 2009), such minimum distances will be important for management considerations. Interestingly, the minimum distance for and frequency of confrontations was considerably less in Øksfjord compared to Setesdal. However, because of too many confounding variables, it is difficult to find a clear explanation for these differences.

For the enclosure experiment, large differences in confrontations were recorded between treatment groups, both within and between periods. Although not significant, variations between the treatment groups in period 1 (pre-treatment) were most likely caused by individual differences and intraspecies dominance interactions within each group of reindeer. Dominance interactions among reindeer typically occur during the rut or when pasture is limited (Skogland 1989). A large decrease in confrontations in all treatment groups during period 2, especially after the initial increase in confrontations in the treatment groups, indicates a cohabituation effect between the resident and visiting animals. The animals likely established an "accepted" hierarchy within the groups. Importantly, the resident and visiting reindeer (RTG) exhibited more aggression than the resident reindeer and visiting sheep (STG) in period 2. This could imply that the two reindeer groups overlap more in their resource use than reindeer and sheep or they have to reestablish a hierarchy within the new and larger group. Interference effects are commonly expected to be greater in more related species (Ferretti et al. 2011) and strongest within the same species, but this has been difficult to document. While there were more confrontations between the resident and visiting reindeer, both groups avoided confrontations resulting in the displacement of one another. Aggression (kicking, headbutting, chasing) between resident reindeer and visiting sheep was recorded only during the first $2 \mathrm{~d}$ in period 2 , showing that the two species cohabituated toward each other within the relatively short time period of $2 \mathrm{~d}$. This again suggests that, in situations where resources are not a constraint, proportions of winning confrontations between resident reindeer and visiting sheep would become more similar if the two species had remained together for a longer period, similar to the two groups of reindeer in Hirotani's (1990) study.

Wild reindeer won slightly more confrontations than sheep and were slightly more dominant toward sheep than semidomestic reindeer. Evidently due to their larger body size, cattle were dominant over red deer (Cervus elaphus) when grazing together in alpine summer ranges in the Italian Alps (Mattiello et al. 1997). Individual body size between the two species is not an important factor in the present study, as the female reindeer and ewes in our study areas were fairly similar in size.

The large majority of encounters resulting in neutral interactions may indicate a habituation effect, and confrontations likely decrease with time. It is uncertain whether the large number of neutral interactions represented a tolerance of the 

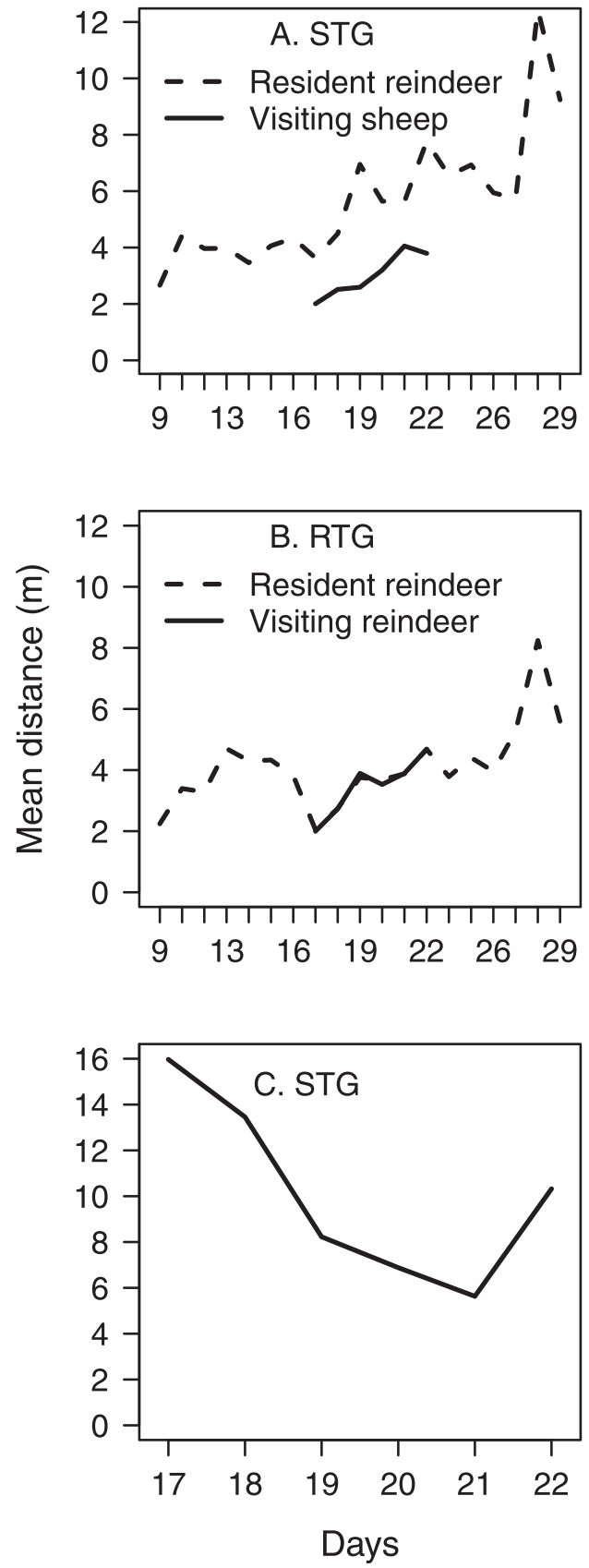

Figure 3. Average distances (A, B) between individuals of same group/ species in RTG and STG treatments, during all three periods (9-29 June 1999) for resident reindeer and from 17-22 June 1999 (period 2) for visiting animals; and (C) between resident reindeer and visiting sheep in the STG treatment in period 2 (17-22 June 1999).

two species toward each other or an absence of intrusion; i.e., the species somehow remained at distances apart from each other that facilitated coexistence, as Grubb and Jewell (1974) described for interactions between unfamiliar sheep within another sheep's home range. Increased confrontations, as distance decreased between the two species, is not likely due to interspecific dominance, as many of the outcomes of such confrontations were similar for both species. These confrontations may also be reactions to getting too close and affecting an individual's own space. The individual space (i.e., the distance at which individuals will tolerate each other) is believed to be 2-3 body lengths in ungulates (Arnold and Dudzinski 1979). This would equal an approximate distance of 3-5 $\mathrm{m}$ for reindeer and sheep (Colman 2000), similar to what we registered in Setesdal $(5 \mathrm{~m})$. Together with the overall low amounts of confrontations, the proximity of individual reindeer and sheep in all our study areas indicates a relatively high degree of interspecific tolerance, especially for the free-ranging semidomestic reindeer (individual reindeer and sheep feeding $0.5 \mathrm{~m}$ apart from each other). Importantly, while interference competition is unlikely to evolve unless there is exploitation competition (Case and Gilpin 1974), even if resources were limited, individuals might have been better off with tolerance toward one another; i.e., costs of aggression could be higher than the benefits (Drickamer et al. 2002). With exploitation competition, food depletion takes place by the first individual, irrespective of species identity, that encounters a resource item (de Boer and Prins 1990). Studies have shown that sympatric grazing results in an increase in intensity of feeding (Arnold and Dudzinski 1979), indicating that each individual/species tries to get its share.

\section{MANAGEMENT IMPLICATIONS}

Our findings revealed a high degree of tolerance between reindeer and sheep, and the two species were able to graze together without much interference ending in confrontation. Confrontations were observed only when the species were closer than $30 \mathrm{~m}$ and $200 \mathrm{~m}$ in Øksfjord and Setesdal, respectively. The number of confrontations increased as the species drew together; supporting our prediction that interferences with confrontation would increase with decreasing distance between the species on shared summer pasture. However, with a relatively high degree of tolerance, an increase in number of neutral meetings will most likely induce a cohabituation effect even at relatively high densities and until perhaps preferred pasture becomes limited.

With a considerable spatial niche overlap in shared food resources between reindeer and sheep, and no interspecific exclusion through interference, one can expect exploitation competition when food resources are limited. The results of the free-ranging studies and the experiment indicate that both species may have the ability to displace each other and thus are able to oust each other from preferred feeding patches if resources are limited. Nevertheless, and despite relatively high densities in Setesdal and the enclosure experiment, a sympatric use of common pastures was not visibly disruptive for either species. Thus, the combined reindeer and sheep density in unison relative to available pasture is important for management decisions.

\section{ACKNOWLEDGMENTS}

We thank Lars Arne Bay, Geir Hovland, and Jon Haugen from Statskog i Sør for practical and logistical support in Setesdal. We are grateful to the families Gaup, Jensen, Simensen, and Mikalsen for their trust and extensive support. C. Bergmann, R. Bjåen, S. Notz, S. Eftestøl, K. Flydal, A. Ims, K. Abel, K. Bay, U. Viggnes, P. Jørgensen, and K. Rapp provided 
Table 5. Habituation with time (days: explanatory variable) in relation to distances (response variable: log transformed) among individuals of same group/species in RTG and STG treatments and between resident reindeer and visiting sheep in the STG treatment in period 2 (17-22 June 1999) under enclosure experiment in Bognelvdalen, northern Norway, analyzed using generalized linear mixed effect model. Repeated observation was used as a random factor. Separate analysis was done for each numbered headings. Resident reindeer was used as a reference level for species categorical variable. RTG and STG refer to reindeer (resident and visiting reindeer) and reindeer-sheep (resident reindeer and visiting sheep) treatment groups, respectively.

\begin{tabular}{|c|c|c|c|c|c|}
\hline Effect & df & Estimate & SE & $t$ value & $P$ value \\
\hline \multicolumn{6}{|c|}{ 1. Among individuals in RTG } \\
\hline Intercept & & -0.51 & 0.29 & -1.77 & 0.08 \\
\hline Visiting reindeer & 1 & -0.001 & 0.05 & -0.03 & 0.98 \\
\hline Days & 1 & 0.10 & 0.01 & 6.61 & $<0.0001$ \\
\hline \multicolumn{6}{|c|}{ 2. Among individuals in STG } \\
\hline Intercept & & -1.50 & 0.95 & -1.58 & 0.11 \\
\hline Visiting reindeer & 1 & -0.57 & 0.09 & -6.67 & $<0.0001$ \\
\hline Days & 1 & 0.17 & 0.05 & 3.33 & 0.001 \\
\hline \multicolumn{6}{|c|}{ 3. Between groups in STG } \\
\hline Intercept & & 3.95 & 0.77 & 5.13 & $<0.0001$ \\
\hline Days & 1 & -0.10 & 0.04 & -2.46 & 0.02 \\
\hline
\end{tabular}

excellent field assistance. We also wish to thank the three anonymous reviewers and the associate editor for their constructive and professional comments.

\section{LITERATURE CITED}

AвRAms, P. 1980. Some comments on measuring niche overlap. Ecology 61:44-49. Altmann, J. 1974. Observational study of behaviour: sampling methods. Behaviour 49:227-265.

Arnold, G. W., And M. L. Dudzinski. 1979. Ethology of free-ranging domestic animals (Development in Animal and Veterinary Sciences). Amesterdam, The Netherlands: Elsevier. $210 \mathrm{p}$.

Arntsen, H. 2007. Interaction between sympatric reindeer (Rangifer tarandus tarandus) and sheep (Ovis aries) on Arctic pastures [thesis]. Ås, Norway: Norwegian University of Life Science. $37 \mathrm{p}$.

Arsenault, R., ANd N. OWen-Smith. 2002. Facilitation versus competition in grazing herbivore assemblages. Oikos 97:313-318.

Bartos, L., D. Vankova, K. V. Miller, and J. Siler. 2002. Interspecific competition between white-tailed, fallow, red, and roe deer. Journal of Wildlife Management 66:522-527.

CASE, T. J., AND M. E. GILPIN. 1974. Interference competition and niche theory. Proceedings of the National Academy of Sciences; 1 August 1974. Washington, DC, USA: National Academy of Sciences. p. 3073-3077.

Colman, J. E. 2000. Behaviour patterns of wild reindeer in relation to sheep and parasitic flies [thesis]. Oslo, Norway: University of Oslo. $104 \mathrm{p}$.

Colman, J. E., R. Eidesen, D. Huermann, M. A. Gaup, Ø. Holand, S. R. Moe, and E. ReImers. 2004. Reindeer 24-hr within and between group synchronicity in summer versus environmental variables. Rangifer 24:25-30.

Colman, J. E., A. Mysterud, N. H. Jorgensen, and S. R. Moe. 2009. Active land use improves reindeer pastures: evidence from a patch choice experiment. Journal of Zoology 279:358-363.

Colman, J. E., C. Pedersen, D. Huermann, Ø. Holand, S. R. Moe, and E. Reimers. 2003. Do wild reindeer exhibit grazing compensation during insect harassment? Journal of Wildlife Management 67:11-19.

CôTÉ, S. D. 2000. Determining social rank in ungulates: a comparison of aggressive interactions recorded at a bait site and under natural conditions. Ethology 106:945-955.

Crawley, M. J. 2007. The R book. London, UK: John Wiley \& Sons. $942 \mathrm{p}$.

dE Boer, W. F., AND H. H. T. Prins. 1990. Large herbivores that strive mightily but eat and drink as friends. Oecologia 82:264-274.
Drickamer, L. C., S. H. Vessey, and E. M. Jackob. 2002. Animal behaviour. New York, USA: McGraw-Hill. 245 p.

ECKARdt, W., AND K. Zuberbuhler. 2004. Cooperation and competition in two forest monkeys. Behavioral Ecology 15:400-411.

FaIRBANKS, W. S. 1994. Dominance, age and aggression among female pronghorn, Antilocapra americana (Family: Antilocapridae). Ethology 97:278-293.

Ferretti, F., A. Sforzi, and S. Lovari. 2011. Behavioural interference between ungulate species: roe are not on velvet with fallow deer. Behavioral Ecology and Sociobiology 65:875-887.

Fischer, L. A., and C. C. Gates. 2005. Competition potential between sympatric woodland caribou and wood bison in southwestern Yukon, Canada. Canadian Journal of Zoology 83:1162-1173.

Forsyth, D. M. 2000. Habitat selection and coexistence of the Alpine chamois (Rupicapra rupicapra) and Himalayan tahr (Hemitragus jemlahicus) in the eastern Southern Alps, New Zealand. Journal of Zoology 252:215-225.

Grubb, P., and P. A. Jewell. 1974. Movement, daily activity and home range of Soay sheep. In: P. A. Jewell, C. Milner, and J. M. Boyd [EDS.]. The ecology of the Soay sheep of St Kilda. London, UK: Athlone Press. p. 160-194.

HIROTANI, A. 1990. Social organization of reindeer (Rangifer tarandus), with special reference to relationships among females. Canadian Journal of Zoology 68:743-749.

Hutchings, N. J., And I. J. Gordon. 2001. A dynamic model of herbivore-plant interactions on grasslands. Ecological Modelling 136:209-222.

Kausrud, K., A. Mysterud, Y. Rekdal, 0. Holand, and G. Austrheim. 2006. Densitydependent foraging behaviour of sheep on alpine pastures: effects of scale. Journal of Zoology 270:63-71.

LAWLOR, L. R. 1980. Overlap, similarity, and competition coefficients. Ecology 61:245-251.

LYNCH, J. J., G. N. Hinch, AND D. B. Adams. 1992. The behavior of sheep: biological principles and implications for production. Melbourne, Australia: CAB International and CSIRO. $237 \mathrm{p}$.

Madhusudan, M. D. 2004. Recovery of wild large herbivores following livestock decline in a tropical Indian wildlife reserve. Journal of Applied Ecology 41:858-869.

Mattiello, S., A. Pozzi, P. Leggeri, M. Trabzala-Marinucci, W. Redaelli, and C. Canzi. 1997. Social and spatial interactions between red deer and cattle in the Italian Alps. Proceedings of the 1st International Symposium on Physiologie and Ecology of Wild and Zoo Animals, 1996. Berlin, Germany: Gustav Fischer. p. 134-138.

Mishra, C., S. E. Van Wieren, P. Ketner, I. M. A. Heitkonig, and H. H. T. Prins. 2004. Competition between domestic livestock and wild bharal Pseudois nayaur in the Indian Trans-Himalaya. Journal of Applied Ecology 41:344-354. 
Moe, S. R., Ø. Holand, J. E. Colman, and E. Reimers. 1999. Reindeer (Rangifer tarandus) response to feces and urine from sheep (Ovis aries) and reindeer. Rangifer 19:55-60.

Mysterud, A. 2000. Diet overlap among ruminants in Fennoscandia. Oecologia 124:130-137.

Person, B. T., M. P. Herzog, R. W. Ruess, J. S. Sedinger, R. M. Anthony, and C. A. ВАВсоск. 2003. Feedback dynamics of grazing lawns: coupling vegetation change with animal growth. Oecologia 135:583-592.

Pinhelro, J. C., and D. M. Bates. 2000. Mixed-effects models in S and S-PLUS. New York, NY, USA: Springer-Verlag. $528 \mathrm{p}$.

Prins, H. H. T., W. F. de Boer, H. van Oeveren, A. Correia, J. Mafuca, and H. Olff. 2006. Co-existence and niche segregation of three small bovid species in southern Mozambique. African Journal of Ecology 44:186-198.

Putman, R. J. 1996. Competition and resource partitioning in temperate ungulate assemblies. London, UK: Chapman \& Hall. 152 p.

R Development Core Team. 2010. The R Foundation for Statistical Computing. Vienna, Austria. Available at: http://www.R-project.org. Accessed 15 January 2011.
ReEd, D. F. 2001. A conceptual interference competition model for introduced mountain goats. Journal of Wildlife Management 65:125-128.

Schoener, T. W. 1983. Field experiments on interspecific competition. American Naturalist 122:240-285.

Skogland, T. 1984. Wild reindeer foraging-niche organization. Holarctic Ecology 7:345-379.

Skogland, T. 1989. Comparative social organization of wild reindeer in relation to food, mates and predator avoidance. Advances in Ethology 29:3-74.

Sushma, H. S., AND M. Singh. 2006. Resource partitioning and interspecific interactions among sympatric rain forest arboreal mammals of the Western Ghats, India. Behavioral Ecology 17:479-490.

Thompson, K. V. 1993. Aggressive behavior and dominance hierarchies in female sable antelope, Hippotragus niger. Implications for captive management. Zoo Biology 12:189-202.

Thomson, B. R. 1977. The behavior of wild reindeer in Norway [thesis]. Edinburgh, UK: University of Edinburgh. $428 p$.

Voeten, M. M., AND H. H. T. Prins. 1999. Resource partitioning between sympatric wild and domestic herbivores in the Tarangire region of Tanzania. Oecologia 120:287-294. 